\title{
The “Grand Tour” as Transformative Experience in Children's Novels about the Roman Invasion
}

Catherine Butler

Published in The Reception of Ancient Greece and Rome in Children's Literature, ed. Lisa Maurice (Brill, 2015), 259-279.

\section{Introduction}

The Roman invasion of Britain, which began in earnest under Claudius in A.D. 43 and was completed over the course of the following three generations, has assumed a unique place in children's historical fiction. It was not the last time that large parts of Britain would face invasion and subjugation by foreign powers, but it is the one that has occasioned by far the most narrative treatments in children's fiction. The arrival of the Germanic tribes who were to form the English heptarchy, like the later invasions by the Danes, occurred in a more piecemeal and less well-documented fashion, and although some attempts at a historical treatment of them have been made ${ }^{1}$ the story of British resistance to the invading English tends to slide quickly away from history into the legendary forms of Arthurian tradition. The Norman invasion of 1066 certainly qualifies as a single, well-documented event that fundamentally transformed the nature of life in England, and might seem ripe for fictional treatment, but while there have been some attempts to do so, for example in Eloise Jarvis McGraw’s The Striped Ships (1991), these have been sparse by comparison with the attention that the Romans have secured from children's authors.

\footnotetext{
${ }^{1}$ For example, Rosemary Sutcliff's The Lantern Bearers (1959), and more recently Philip Reeve's Here Lies Arthur (2007).
} 
There are numerous possible explanations for this focus. One, which Hallie O’Donovan and I explored at length in Reading History in Children's Books (2012), ${ }^{2}$ concerns the ambiguous position of Romans and Britons in British consciousness, with modern Britons perhaps identifying with their ancient forebears in nationalistic or racial terms, but recognizing themselves more easily in the Romans in terms of literature, architecture and culture. This ambiguity manifests itself along other axes too, especially for those readers who like to extrapolate from particular historical periods to a more general sense of history's shape and direction. Children's novels dealing with this period frequently identify the Roman invaders with notions of progress or modernity, while the Britons are often depicted in ahistorical, static terms, or even as barbarians. While some texts and their readers may approve the coming of the Romans as a necessary step on the road to civilization, which helped drag Britain into the first century A.D., those who prefer to construct pre-Roman British society as an ecologically sustainable idyll will deplore the change.

In Reading History in Children's Books we considered these questions from a number of perspectives, but our discussion was largely confined to Britain itself. In this essay I will examine a selection of novels, ranging in date from the late nineteenth to the early twentyfirst century, that depict their protagonists travelling between Britain and the European mainland - in most cases as far as Rome itself. For this common trope I have chosen the convenient if anachronistic label of the Grand Tour. This conveys something of the way in which such journeys are used to educate characters, and introduce them (and, vicariously, the books’ readers) to a variety of cultures and experiences - sometimes occasioning a

\footnotetext{
${ }^{2}$ See especially the chapter "The Eagle Has Landed: Representing the Roman Invasion of Britain in Texts for Children” (17-47).
} 
“conversion” to a point of view more sympathetic to Rome than that with which they set out. The circumstances of these journeys, carried out in the context of the Roman invasion and its immediate aftermath by characters who are usually slaves or hostages, of course contrasts sharply with those in which the privileged youth of Britain made the real Grand Tour in the eighteenth century; but the trope sheds useful light on the questions of identity and cultural education that loom large within this genre.

\section{Beric, the Victorian Briton}

G. A. Henty's Beric the Briton (1893), the earliest of our Grand Tour books, is the work of a man described by his colleague Edmund Downey as "the most Imperialist of all the Imperialists I ever encountered” (quoted in Butts, 152). As such a description may suggest, Henty saw his writing as having an exhortative role in inspiring his readers - his "Dear Lads", as he frequently addressed them in his prefaces (Butts, 153) - to take up the mantle of empire. His protagonists are models for emulation, and their exemplary adventures generally take them on foreign quests for adventure and glory. Dennis Butts summarizes the pattern of a typical Henty novel:

After a crisis near the beginning of the book... probably connected with the loss of a fortune or the death of his father, the hero, who has already shown some taste of his mettle by defeating the school bully or catching a thief, sets off on a series of adventures in each of which he triumphs, before a culminating crisis, which again is successfully surmounted and followed by a prosperous homecoming. (155)

Henty's primary territory is the period of British Empire, from its early days (With Clive in India [1884]), through the Napoleonic wars (One of the $28^{\text {th }}$ : a Tale of Waterloo [1890]) and 
into modern times with such works as With Kitchener in the Soudan (1903). Unsurprisingly, Henty's imperialism finds a congenial habitat in the story of the Empire's own growth. Not all Henty’s novels concern the British Empire, however. His secondary aim was to introduce his British readers to the past of their own country, and particularly its military history. His Preface to Beric the Briton sets the book explicitly in the context of this aim: "My series of stories dealing with the wars of England would be altogether incomplete did it not include the period when the Romans were masters of the country” (5). The history of the British Empire and the history of England are far from coterminous, and those points at which the English (or their predecessors) have been in a position of opposing the imperialist enterprises of other nations inevitably form points of ideological tension. When imperialism and patriotism collide, which is to be preferred? Shorn of patriotism, moreover, what justifies the imperialist impulse? Without that penumbra, is it not exposed as (to quote Joseph Conrad's Marlow) mere "robbery with violence” (72)? In By England's Aid: the Freeing of the Netherlands, 1585-1604 (1891), for instance, Henty invites his readers to cheer the resistance of the Dutch and their English allies to the arrogance of imperial Spain. Beric the Briton, published two years later, occupies a more complex ideological and historical territory. It is the patriotic story of a Briton involved in "a desperate effort to shake off the oppressive rule of Rome" (6), as Henty puts it in his Preface. However, it is also the story of the overture to Britain's own imperial theme, with the Romans being presented as the conduit for principles, technologies and other features (including Christianity) that were to prove prerequisites for Britain's own future power, as well as providing an archetypal model for the practice of empire itself. Without the example of the Pax Romana, the Pax Britannica would lack much of its ideological resonance. 
Beric the Briton tells the story of Beric, the young leader of a sub-tribe of the Iceni known as the Sarci, living in the 50s A.D. Having grown up as a hostage in the house of a Roman in Camalodunum (Colchester), Beric has an intimate familiarity with the Romans’ customs and has come to admire their justice, organization and literature; but when he returns to his tribe it is at a difficult moment in Roman-British relations, with anti-Roman sentiment running high. Knowing that there are likely to be Roman spies amongst his tribesmen, Beric finds himself steering a tricky course from the beginning - wishing neither to be seen fomenting trouble, nor to appear to have "gone native” during his time as a hostage. In the event, his knowledge of Roman military tactics proves invaluable when Boadicea raises the tribe, and he leads his people to several victories in battle, as well as a successful guerrilla war in the East Anglian swamps after Boadicea’s defeat by Suetonius. Betrayal leads to eventual capture, however, and Beric (with some of his men) finds himself shipped to Rome as a slave. Initially he works as a gladiator, where he gains acclaim by saving a Christian girl from being killed by a lion, defeating the animal unarmed. The Emperor Nero then employs Beric as his private bodyguard, until Beric is again betrayed and forced to flee the imperial palace with his men. Thereafter they live as outlaws in the hills south of Rome, eventually winning a reprieve when Nero is overthrown by Galba. The story ends with Beric (by now married and a Christian) being sent back to Britain in order to rule over his people as a Roman provincial governor.

Henty's presentation of Beric's eventful career, while it shows his hero as unswervingly principled, capable and heroic, nevertheless describes a startling reversal of loyalties. Near the beginning of the book, his mother Parta admonishes him: 
I need not tell you not to let them Romanize you. You have been brought up to hate them. Your father has fallen before their weapons, half your tribe have been slain, your country lies under their feet. I will not wrong you then by fearing for a moment that they can make a Roman of you. (17)

By the end of the narrative, however, Beric has become a functionary of the Roman state; and although he rules his people with justice and wisdom he does so under Roman authority. Indeed, it is made clear when he takes up the post that Rome's choice of a native governor is in itself partly a tactic aimed at ensuring the continued subjugation of Britain. His Roman friend Muro, who proposes him for the role, explains that he has stressed to the Emperor that Beric "would in all things be faithful to Rome" and use his "influence to the utmost to reconcile the people to [Roman] rule” (375). On Beric’s arrival back in Britain, the propraetor Trebellius expands on this point:

I am convinced that it is the best policy to content a conquered people by placing over them men of their own race and tongue, instead of filling every post with strangers who are ignorant of their ways and customs, and whose presence and dress constantly remind them that they are governed by their conquerors. (379)

Not only is Beric an instrument of Roman power, he is a particularly insidious instrument that allows the Britons to be seduced into subjection more effectively than naked oppression could do. Trebellius's sentiments complement Tacitus's observation in the Agricola that conquered tribes such as the British, in adopting Roman luxuries and customs, forget that 
these are the trappings of their own slavery ${ }^{3}-$ a thought earlier echoed by Beric's friend Boduoc on seeing the Romanized Gauls: "they appear to have adopted the Roman dress and tongue, but for all that they are slaves” (183). Trebellius on the one hand and Boduoc on the other describe two of the primary ways by which Rome encouraged conquered peoples to become reconciled to their position: first by believing they have retained their native identity, and then by believing that they have gained Roman identity. Romanized native rulers such Beric smooth the transition from one belief to the other; but in both the subject peoples are deceived.

The conundrum posed by Beric is that of a character who turns from being a patriotic warrior devoted to expulsion of the Roman invaders from his homeland into a loyal servant of Rome working to maintain and entrench its power over his people, but who does so without any sense - either from his own point of view or that of the narrative - that he has been inconsistent. Beric undergoes no dramatic conversion to the Roman point of view (he already admires them at the beginning of the novel), nor is he ever presented other than as a fit character for readerly admiration. How can this circle be squared? Ultimately it cannot, the contradictions in Beric's presentation reflecting unresolved conflicts at the heart of Victorian imperialist ideology. However, the text adopts several strategies in order to soften the sense that an inexplicable volte-face has been performed. In doing so, it draws on a number of existing cultural ideas that were in wider circulation in Henty's time, aimed at justifying empire in general and British imperial rule in particular.

In so far as the question of Beric's changing attitude to Roman power is addressed explicitly by the text, it is in terms of pragmatism. An accommodation must be reached with Rome,

\footnotetext{
${ }^{3}$ Compare the Agricola 1.21: "Idque apud imperitos humanitas vocabatur, cum pars servitutis esset".
} 
simply because Roman power is effectively invincible, and the alternative to doing so is annihilation. It is in this context that the trope of the Grand Tour comes into play. When Rome is perceived in terms of a few thousand legionaries stationed far from home, victory seems conceivable; but once Beric and his friends find themselves in the city itself, the futility of their task is borne in upon them:

Beric rejoined his companions. "Well, Boduoc, what think you of Rome?”

"I have been thinking how mad our enterprise was, Beric. You told me about the greatness of Rome and from the first predicted failure, but I thought this was because you had been infected by your Roman training; I see now that you were right.” (199)

Significantly, Henty gives this observation not to Beric but to his passionate friend Boduoc, who has been established from the book's opening pages as the more virulently anti-Roman character. Here is someone who cannot be accused of Roman bias, but who now accepts not only that defeat was inevitable but that even the attempt at resistance was, rather than being noble or heroic, simply "mad”. This pragmatic recognition of the realities of military power is not elsewhere a prominent feature of Henty’s book, which tends to glorify risky feats of derring-do such as fighting a lion unarmed, and depicts daring enterprises as both successful and admirable, but that discourse of heroism takes place within the parameters of a broader political narrative far more respectful of political and military reality.

Henty also finds various ways to efface the distance between Beric and Rome. Most obviously this is achieved by giving Beric experience of life in a Roman household, which makes him from the beginning a culturally hybrid character. Not only has he learned (and 
learned to admire) Roman customs, language, and military technique, but he is a keen reader - an accomplishment baffling to Boduoc and the other illiterate Britons. More subtly, the Britons’ sensibility often appears to recall Roman models and values. Beric’s mother Parta is portrayed as a stern matriarch in the tradition of Volumnia or Portia, given to voicing such Horatian sentiments as "He can but die once; he cannot die in a nobler effort for his country" (93). The tribal elder Aska shows that, like Boduoc, he has let neither illiteracy nor anachronism be a bar to familiarity with the Agricola when he remarks that "Rome cannot wish to conquer a desert” (163). ${ }^{4}$ In general, Henty makes little effort to construct or evoke a specifically British worldview distinct from that of Rome. Points on which the differences between Roman and British sensibilities might be expected to be particularly stark, notably in the matter of religion, are generally underplayed. When asked about native religious practices, for example, Beric deflects the conversation, remarking that "These mysteries are known only to the Druids” (187). Although Henty occasionally draws attention to areas in which the ancient world differs from his own he typically does so in order to highlight ways in which the Romans and British resemble each other: "In the age in which [Beric] lived feelings of compassion scarcely existed. [...] Beric, being by birth Briton and by education Roman, felt no more compunction at the sight of blood than did either Briton or Roman” (251). This anthropological note surfaces only rarely in Beric the Briton, however: more often, Beric has the accent and temperament of a Victorian British officer - and so in most cases do the Roman characters with whom he has to deal.

The melding of Roman and British characters may be an authorial strategy, but it is also a political policy within the text, which Beric himself espouses. On his way back to Britain to take up his governorship, he and his followers obtain clothes that are a deliberate "mixture of

\footnotetext{
4 “Ubi solitudinem faciunt, pacem appellant”: Agricola 30.
} 
that of the Britons and Romans, having the trousers or leggings of the British and the short Roman tunic” (378). This unlikely garb functions as a visible symbol of the cultural hybridization to which he aspires. Cultural and indeed racial hybridization was a perennial theme of Victorian (and later) writers about the British at the time Henty was writing (Hingley, 94-95). Given the “mongrel” nature of Henty’s British readership, most of whom had some mixture of Celtic, Anglo-Saxon, Viking and Norman in their heritage, it was necessary to construct ways of recounting British history that made positive use of its multiple invasions and mass migrations, while still claiming for the British a distinct, indeed unique, character and position within the modern world. One way of doing this was to suggest that this racial mixture constituted the ingredients in a recipe that resulted in the modern British, who were able to draw freely on the strengths of the all their disparate ancestors. Another strategy was to write of the challenges of history as constituting a kind of training. The latter approach can be seen clearly in a text such as C. R. L. Fletcher and Rudyard Kipling's A History of England (1911), in which English defeat at the hands of the Normans, for example, is presented as a prerequisite for future achievement:

The Battle of Hastings decided, though not even William knew it, that the great, slow, dogged English race, was to be governed and disciplined (and at first severely bullied in the process) by a small number of the cleverest, strongest, most adventurous race then alive. Nothing more was wanted to make our island the greatest country in the world. (43)

Fletcher and Kipling take a similar line when addressing Britain's earlier subjugation by the Romans, suggesting that it was a "misfortune" that the conquest did not extend to the whole island and contrasting Britain’s subsequent fate with that of unconquered Ireland, "which 
never went to school, and has been a spoilt child ever since” (21). Although Henty too notes that the Britons have much to learn from the Romans, his emphasis is not only on education but also on the effects of interbreeding. In his account, the advantages and disadvantages of mixing the British race with that of the Romans and of the foreign traders and craftsmen who came to Britain in their wake are quite finely poised. The British warriors, it is stressed throughout the narrative, are physically superior - tall, blond, muscular men, whose strength and size make them individually more than a match for their Roman conquerors. However, Henty suggests that sacrificing these qualities through intermarriage may have been a price worth paying:
Although [intermarriage] in the end had the effect of diminishing the physical proportions of the British, and lowering the lofty stature and size that had struck the Romans on their landing with astonishment, it introduced many characteristics hitherto wanting in the race, and aided in their conversion from tribes of fierce warriors into a settled and semi-civilized people. (383)

Henty is probably referring here to the acquisition of desirable racial characteristics rather the trappings of civilization alone, but he does not specify which physical or mental features lacking in Beric and his compatriots were supplied by the Romans. Indeed, his vagueness on this point may be strategic.

Rachel Johnson has pointed out that several of Henty’s books about the British Empire include “characters whose views, although initially opposed to English rule, change after personal contact with the colonisers", and who become "advocates for what is perceived as the more advanced civilisation and for an integration of aspects of that civilisation, just as 
Beric does” (78). This is fair comment, but Beric the Briton is not purely a conversion story, since Beric is already well disposed to Roman civilization at its inception. Although Roman power and military dominance are driven home by Beric’s sojourn in Roman, there is no need for Henty to spell out lessons about Roman cultural superiority, and indeed his narrative is fairly nuanced on this point. While Beric admires Roman literature and the Stoicism of individuals such as his future father-in-law, he maintains a studied neutrality with regard to most aspects of Roman life. Rather than praise or condemn Nero he exhorts his men to stand aloof from domestic politics: "it is no business of ours, strangers and foreigners here, to meddle in the matter” (286). The enthusiasm for Rome evident in some post-Second World War texts is muted here. Nevertheless, Henty's book establishes a number of tropes that will recur in later texts featuring British protagonists who find their way (willingly or otherwise) onto the Continent. The visceral impression made by Rome’s vastness, magnificence and power, a visit to the arena (preferably involving a fight with a lion) and a telling encounter with the Emperor were amongst the features that would recur in later Grand Tour novels.

\section{The Grand Tour in the 1950s}

If any decade can be identified as the age of novels of the Roman invasion, it is the 1950s. The number of books devoted to this topic reflects the general prominence of historical fiction at this time, and the appearance of such classics as Rosemary Sutcliff's The Eagle of the Ninth (1954) no doubt inspired emulation. It is also worth noting however that this decade was one in which Britain's relationship with the idea of empire was at a particular crisis, and that Roman Britain offered parallels through which to explore the issue in historical fiction. In the 1950s Britain found itself on both sides of the imperial equation: an imperial power in its own right (if a declining one), but also a nation attempting to reconcile itself to a diminished status in the world and to forge new relationships with larger political blocs, be 
they the United States (the world’s new “Roman” power), the fledgling European Community, or even with the wraith of Empire in the form of the British Commonwealth. Books could provide psychological models for this transition in status, showing how one could maintain psychological and moral integrity in a changed world, and combine selfrespect with the recognition of the realities of politics and power.

For an example of a narrative that really does show the protagonist "converted" from an antiRoman to a pro-Roman position we cannot do better than Henry Treece's Legions of the Eagle (1954), written some sixty years after Beric the Britain. This novel tells the story of the young Briton Gwydion, who is captured after the Romans’ initial assault on Camulodunum and taken as a servant to Gaul. Like Beric, Gwydion sees his home and way of life destroyed by the invading Romans; like him he loses a parent in the process; like him he is sent in captivity to the Continent. Gwydion is understandably antagonistic to the Romans at the start of the novel; however, Legions of the Eagle shows a change of heart far more wholesale than that of Henty’s protagonist. Once settled in Lugdunum (Lyon), Gwydion draws a stark comparison between the British and Roman ways of life, much to the latter's advantage:

So much of Britain was a wilderness, where wild beasts roamed, and where people almost as wild as the beasts held their festivals of blood and suffering. [...] As the boy speculated on the land of his birth began to wonder why the Romans had even bothered to come to Britain. What he had seen of Roman Gaul was good; it was a wellregulated land, with good roads, inns, and houses; a land where men paid their taxes in money, not in blood-and where, in return for those taxes, they were given something of value, the protection of the greatest army the world had ever known. (140) 
In Legions of the Eagle Gwydion's conversion to the Roman cause is set off by an almost wholly hostile estimate of the British, who in the book's latter half are portrayed as untrustworthy savages. The Silures of South Wales in particular are singled out as sullen ingrates who, unlike Gwydion himself, are insusceptible to civilization. Treece even has a Roman character refer to them as "black-faced cannibals” (149) recalling the way that the racist iconography of European "first contact" in Australia and Africa was was co-opted by earlier writers about the Roman invasion, Henry Ford's illustration of the Kent coast in A.D. 43, which appeared in Fletcher and Kipling's A History of England, being a striking instance:

\section{[INSERT ILLUSTRATION 1 HERE]}

Henry Ford, 'The Landing of the Romans', from A History of England (17)

Ford's cringing, dark-skinned Britons are a world away from Henty's noble blond giants, and it is to Ford's tradition rather than Henty's that Treece is committed in Legions of the Eagle. By the book's conclusion Gwydion is comfortably established as a small farmer in Gaul, and has come to consider British resistance to the Romans, such as that of his former clan chief Caratacus, as the recklessness of a "madman" (163), a word that in his mouth carries a weight of moral condemnation very different from Boduoc's estimate of resistance to Roman power as "mad” because of its futility.

Most invasion texts written in the 1950s are broadly sympathetic to the Roman cause, although few are as extreme as Treece's. We will briefly consider two others, Lydia S. Eliott's Ceva of the Caradocs (1953) and Geoffrey Trease's Word to Caesar (1956) in order to show something of the range of purposes for which the Grand Tour trope could be used at this period. Both establish or assume a pro-Roman view, and both have the striking feature 
that the protagonists spend much of the book seeking justice through a private audience with the Emperor Hadrian, although in other respects the attitude to European adventure is strikingly different.

Ceva of the Caradocs concerns a great-great-granddaughter of Caractacus, who at the time of the novel's opening is facing the decision of whether to stay on in a hill fort on the Wrekin with her grandfather Gaelan, the local chief, or join her parents in the new Roman town of Viroconium (Wroxeter). Her love for her grandfather notwithstanding, Ceva’s preference is clear: she is a close friend of the Roman governor's daughters, and longs to share in the amenities of the city. Ceva's politics are summarised by a question that she asks of her horse early in the narrative: "Is it awful of me to be glad [...] that the Romans have made Britain a part of their marvellous Empire?” (9). When the Emperor Hadrian visits the settlement she is thrilled to be one of the girls chosen to dance before him, an act that that prompts the jealous Druids to order her kidnapping and - through a series of mischances - occasions her being taken as a prisoner across the Channel.

Like Legions of the Eagle, this is a notably pro-Roman text, but the trope of the Grand Tour functions quite differently. Although Ceva of the Caradocs includes a conversion narrative it belongs not to Ceva herself but to her grandfather. The events of the narrative prove to Gaelan that his attachment to the old ways and resentment of the Romans are both misplaced. Although Gaelan begins the novel by paraphrasing Tacitus ("Though he calls it bringing us civilization, it is his way of enslaving us” [19]) and is understandably reluctant to compromise with a state that hunted down his grandfather and put a price on his own father's head, he comes during the course of the book to understand that the Romans are a force for good, and that in the words of the Caradoc family motto he should move "Forward, not 
backward” (8) - a decision made easier by the dishonesty and benighted superstition of the Druids. The catalyst for this change of heart is Ceva's kidnapping, which occasions an affecting if unlikely interview between local chieftain and Roman Emperor:

They were both great men and in their greatness understood each other, and they talked freely together of the problems of both Britons and Romans.

“Do not call me great,” Hadrian had said. "It is you, Chief Gaelan, who have the greatness of spirit, and I shall not be happy till your granddaughter is found and brought back to her home in safety.” (66)

Eliott is not meticulous with respect to historical accuracy, and although she demonstrates some knowledge of Roman dress and customs her text is steeped in the world and popular fiction of the 1950s, which tend to bleed through the Roman narrative at times. The kidnappers who take Ceva prisoner betray their class origins through their uncouth speech (““What yer want?’ he bawled” [58]) as surely as any Enid Blyton villain; Gaulish characters have names such as "Master Antoine”; and characters say things like "Matild's a saint to put up with you” (157), in a way that sits awkwardly with Ceva's belief in the Druidic "Unseen One”. Ceva's lot in Gaul and Italy is certainly harder than that of the average 1950s debutante sent to a Continental finishing school, but the primary effect of her European sojourn is to teach her personal values of self-reliance and courage, and generally to hasten her growth into maturity, rather than to introduce readers to the world of the second century A.D., let alone explore broader issues about culture and imperialism. Although she spends much of the book trying to get to Rome to find Hadrian, this is purely part of her personal escape plan, for she is sure he will recognize her and send her safely home. Thus, while the desire to reach the 
centre of Empire is passionately expressed it is only ever a stepping stone on the road to Shropshire: “Rome! I shall get there. I will get there. Home! Grandfather, Matild, Mamma Carola! Oh, do help me to get there!” (224).

Ceva eventually does arrive in Rome, or rather at a villa on its “outskirts” (249), but there is no indication that she ever ventures further in, and Eliott provides no description of the city. Even Hadrian is absent (though he sends a friendly letter from Spain), and within two pages Ceva is on her way back to Britain. The climax of the book comes not with the arrival in Rome or the ever-deferred meeting with Hadrian, but with a marriage proposal from the handsome son of the Viroconium governor, which takes pride of place in the last lines of the book.

Unlike Eliott, Geoffrey Trease was, from the beginning of his career, a self-consciously political writer, who made his name with books such as Bows Against the Barons (1934), in which the socialist class struggle of the 1930s is transplanted into Robin Hood's greenwood. Over time Trease drew back from the kind of overt didacticism that characterized his earliest work, however. The impetus behind Word to Caesar, as he describes it in his 1974 memoir Laughter at the Door, was internationalist but not specifically socialist in spirit. Rather, it was an attempt to get beyond what he saw as the insularity of British historical fiction:

When I planned the book, I was anxious to get away from the national bias which, in so many stories of that epoch, seems to suggest that the Romans are interesting only as the invaders of Britain. I wanted to tell children about the Romans in Italy, the Romans of the Silver Age of classical literature (I worked in an exiled poet, another Ovid with altered dates) and above all the Romans of a peaceful, efficiently united 
Europe, the empire of Hadrian. But in dealing with an apparently remote period and setting one must establish a bridge, so I felt it best to open the tale with Hardknott and Ravenglass in Britain, and then set the plot moving that would carry my hero to Arles, Ostia, Rome and the Bay of Naples. (24)

Writing barely a decade after the end of the Second World War, and on the eve of the founding of European Economic Community in 1957, Trease’s wish to conjure for young readers saturated in the literature of conflict the idea that Europe need not be a cockpit for war is understandable. A narrative about the joys of a stable political settlement and a “peaceful, efficiently united Europe” do not make for the kind of action-packed adventure in which Trease specialized, however, and like Eliott's his novel is largely a personal rather than a political story. It begins with a battle (a British rising against the Ninth Legion at Hardknott in Cumbria, on the fringes of the Empire) but it is impelled not by military or political considerations but by the need for the narrator, Paul, to clear an innocent man's name and defeat a master criminal - something he can accomplish only by gaining the ear of the Emperor himself. The Empire, as the background to Paul's life, is as inevitable and unquestionable as the sky, and some 80 years after the Claudian invasion it is viewed by Paul as an irrevocable fact. “Is empire a good thing?” muses one of the other characters early the book, a question to which Paul responds with bemusement: “I gasped. Was empire a good thing? I could not imagine life without the Empire” (39). The matter is not raised again. Paul is however aware of himself as a product of Empire. The son of a Roman soldier from Spain and a British mother, he is an embodiment of the kind of intermarriage that Henty's narrative had anticipated - “a bit of a mixture, with Father’s dark eyes and sharper features but Mother’s lighter hair and skin” (3). Paul is also international in outlook: he leaves Britain, where he has spent all his life, early in the story, but there is no sense of deracination. Rather, 
he is curious to see other parts of the Empire, and even at the story's conclusion is preparing to accompany Hadrian on his forthcoming journeys to its outer reaches, rather than thinking of a return to his birthplace. Rome itself, which he has longed to see all his life, does not disappoint, and he surveys it with the slack-jawed wonder suitable to a provincial youth:

Here I was in the city I had dreamed of all my life, and even in my wildest dreams I had never seen anything so vast, so magnificent. Ten massive bridges spanned the river, four hundred temples sent their spiced incense floating up to Heaven, triumphal arches framed the view down every street (or so it seemed to me then), the public parks and gardens made a countryside within the city, hundreds of acres of grass and woodland... and converging on Rome like marching columns of soldiers came the aqueducts, lofty and proud upon their striding arches, bringing fresh water from the hills, ten, twenty, thirty, even forty miles across the plain. (174)

In Word to Caesar, this magnificence is not significantly undercut even by the admission that thieves and corrupt officials are numbered amongst Rome's citizens, for these are shown to be adequately dealt with by the power of law as personified in Hadrian. Trease's novel shares with Eliott's not only its focus on private criminality rather than war or imperial oppression as the engine of the plot; it also uses the figure of the Emperor as the ultimate guarantor of order and justice. In Trease's case, this is a strategy that he had already employed in his earlier book set in sixteenth-century England, Cue for Treason (1940). In that book, the protagonists Peter and Kit spend much of the narrative attempting to bring a plot against Elizabeth I's life to her attention, and are duly rewarded with the restoration of Peter's family's fortunes and the favour of the queen. In Word to Caesar we find a similar pattern: Hadrian's power is both absolute and benevolent, and once convinced of the innocence of 
Paul's friend Severus he does not hesitate to recall him from exile and accept Paul into his entourage. “Don’t thank me for justice, child,” he tells Paul. “That is what I am here to do. Justice” (278). The Hadrian of Eliott's book too is a paragon of civic duty and benevolence, who takes a good deal of time out from running the Roman Empire in order to direct the search for the missing British girl. Ceva gushes at one point, "I wonder he doesn’t spend his life living in [his lovely villas] and being happy himself instead of travelling from end to end of his Empire, trying to make things safe and happy for the Gauls and the Britons and lots of other people” (19). The rhetoric resembles the kind of sycophantic coverage traditionally afforded to the British royal family by their admirers - and is an endorsement not just of Hadrian the man but of the institution of imperial power that he embodies - an endorsement from which neither text significantly diverges.

For all his vocal commitment to imperialism, of the authors we have so far considered it is Henty in Beric the Briton whose text is the most ideologically intricate. His novel, being set at the time of the Roman invasion and told from the point of view of one of the Britons, inevitably asks more searching questions of the realities of imperial power than texts set several generations later when that power has become a fait accomplit, as with Eliott and Trease; and although it is sympathetic in its attitude to Roman civilization it has none of Treece’s fierce animus against the Britons and their culture. Moreover, in prominently featuring a notorious tyrant such as Nero, Henty gives imperialism a face that is harder to reconcile with good government or a "civilizing mission" than is the case with Hadrian, the third of the five so-called "good emperors” under whom (in Gibbon's famous phrase) "the Roman empire was governed by absolute power, under the guidance of virtue and wisdom” (Gibbon, 85). However we might quibble with Gibbon's assessment there is no denying that Hadrian is a stronger contender than Nero or indeed Claudius to be the acceptable face of 
imperial autocracy. Indeed, as the passage from his memoir quoted above suggests, Trease appears to have chosen him with that consideration in mind.

\section{The Anti-Imperial Theme}

In Reading History in Children's Books we noted a tendency for children’s books published in recent decades, and particularly since the turn of the twenty-first century, to adopt a far more sceptical and even hostile attitude towards the Roman invasion and occupation of Britain than was the case in the past. This hostility has a number of different facets. It may for example take an environmental cast, with the Britons being identified as a people in tune with nature and identified with their land through their spiritual beliefs, a depiction clearly influenced by modern paganism, although the notion of Druidism as a nature-based religion goes back much further (Hutton, 79-92). The hostile framing of Rome may also draw on scepticism about international capitalism and multinational corporations, with the Romans’ perceived obliviousness to the local landscape and culture (straight roads cutting through sacred groves, identikit forts replicated from York to Palestine) being parsed as arrogance and wilful blindness rather than admired as evidence of efficiency, organization and engineering skills, as might have been the case when mass production and Brutalist architecture were more in vogue in the middle of the twentieth century. Most importantly, the ideology of empire itself has long since ceased to be acceptable. Post-colonial perspectives in both literature and politics have made the voice of subaltern populations far louder, and modern treatments of the Roman invasion are far more likely than before to see it in terms of military aggression rather than as a conduit for civilization.

Pauline Chandler's The Mark of Edain (2008) is a good example of a modern anti-Roman book that uses the trope of the Grand Tour for rather different purposes than Henty or his 
1950s successors. Its protagonist is the British girl Aoife, who is a niece of Caradoc (Caratacus) and has lived for several years as a hostage in Rome, along with her brother Madoc. On the eve of his invasion, Claudius - here depicted unsympathetically, as a vain and cruel dictator - decides that it will be politically useful to take them to Britain with his army. Aoife finds herself travelling with the invasion fleet, and on the way she befriends one of Claudius's war elephants, with whom she comes to have a preternatural affinity - something that gives her a reputation for witchcraft and magic amongst the Roman troops. Aided by various Celts amongst the soldiery and traders she meets en route, Aoife (who by now has inherited the leadership of her tribe) eventually escapes and finds her way to the stronghold of Caradoc, who is leading the struggle against Rome. The novel ends, as did Ceva of the Caradocs, with its heroine embracing a Roman soldier - but in this case the officer, Justinian, has cast aside his Roman identity and reverted to his original name of Huw.

We have already alluded to one of the most significant ways in which The Mark of Edain differs from the earlier books we have considered. Rome's invasion is here presented not as the coming of civilization, nor even as the inevitable way of things at a period when war was a universal way of life, but rather as the selfish project of a capricious ruler. Although Chandler makes customary reference to the efficiency and training of the Roman army (10), the Roman soldiers she actually depicts are superstitious and rather incompetent, and cruel in the way they lord it over the peasants on the coast near Massilia (perhaps a little anachronistically) as an army of occupation (86). Even Rome itself, in contrast to the breathless description of Trease's Paul, appears unimpressive from Aoife's viewpoint, as she floats away from it down the Tiber: 
The city looked small, insignificant, as Aoife looked back from on board the raft she was riding with Bala. Slowly the great hub of the wheel of the Empire shrank and disappeared round a bend in the Tiber. Her spirit shook itself free like a bird. Great Rome was, after all, only buildings, dusty streets. (70)

Inverting the trope of "Great Rome" is one part of the rhetorical repositioning carried out in The Mark of Edain's use of the Grand Tour topos. The other is the invention of a pan-Celtic nationality and culture, of which Aoife's own tribe is but a small part. Aoife and Madoc (the combination of Irish and Welsh names is significant in this context) view themselves, and are viewed by the Romans, primarily as Celts rather than as Britons, contrary to the linguistic practice of the ancient world. Moreover, Chandler's Roman characters regularly employ the neologism “Celtish” as a general adjective, implying an overarching cultural or ethnic identity amongst Celtic peoples that might provide a counterweight to the Mediterranean culture of the Romans. ${ }^{5}$

Despite its anti-Roman position, however, The Mark of Edain retains some elements of those earlier books in which a pro-Roman point of view is normative. Like the British characters in Beric the Briton, for example, Aoife and Madoc partly adopt Roman habits of speech and thought, with Aoife dropping a casual “ergo" into conversation early in the book (9). Even the word "Celt", as they are aware, is of Greek origin, and Aoife thinks of her home island as Britannia, a notably Latinate eponym. More significantly, those British who are resisting the Roman invasion, including Caradoc, are consistently described by Aoife and everyone else in

\footnotetext{
${ }^{5}$ Compare the narrator of Jim Eldridge's Roman Invasion (2008): “We Britons are Celts from the great Celtic race, whether Brigante or Trinovante or Caledonian, or from across the water to the west where the Isles lie" (50).
} 
the book as "rebels" - a usage that concedes the Roman claim to dominion over Britain from the start.

The Mark of Edain resembles the other texts we have considered in evincing a complex and contradictory attitude towards the cultures it represents. In the case of this text we may say that its apparent ideology - its unflattering portrait of the Roman emperor and state, and by extension of the oppressive practices of empire, as well as its emphasis on respect for nature, evinced in Aoife's care for the elephant Bala - is to an extent problematized and even undermined by its adoption of language and attitudes that tend to legitimate Roman and imperialist viewpoints. To avoid this entirely would be a difficult task, though, given the extent to which Roman culture and language permeate the modern West, and the inevitable indebtedness of novels such as The Mark of Edain to a long tradition of fiction about the Roman invasion in which views broadly sympathetic to the Empire were entrenched.

The trope of the Grand Tour is by no means universal in books about the Roman invasion, but it is common and its widespread nature reflects its obvious utility in providing a comparative view of two or more cultures. However, within that broad remit, as we have seen, it can be employed for numerous purposes. In Beric the Briton, Henty both contrasts the Briton and Romans, particularly in terms of their physique and general appearance, and also makes a case for the universality of humanity. As the philosophical Roman Norbanus puts it: "Human nature is the same everywhere, [...] fair or dark, great or small. It is modified by climate, by education, by custom, and by civilization, but at bottom it is identical” (197). To find uniformity of human nature is not, however, to espouse equivalence between civilizations - and one implication of Norbanus's words, as of Henty's book, may be that nowhere should be considered off limits for imperialism's civilizing mission. This is a view 
prosecuted in a rather more simplistic way by Henry Treece's Legions of the Eagle, although that book appears at times rather more sceptical of the ability of some Britons to appreciate the Roman gift of civilization. Henty had used Beric’s journey from Britain to Rome as a way of convincing his men of the practical inevitability of Roman victory; but for Treece, providing his protagonist Gwydion with the opportunity to travel to Gaul (even though he goes as a slave) is a way of opening his eyes to the superiority of Roman culture and indeed the repellent nature of the British way of life.

The effect of the Grand Tour is different again in Trease's Word to Caesar and Eliott's Ceva of the Caradocs. Trease's book contains no significant British characters beyond the early appearance of a native girl, Barbara, who flatters the protagonist into betraying his father's fort, thus making it vulnerable to a native uprising. The woman who seduces the hero into revealing the secret of his strength is an old trope that bears more examination than there is space for here, but while this incident leaves a negative impression of the Britons as brutal and sly the book swiftly moves leaves them behind as it moves into its main project of providing its Romano-British protagonist with an eventful tour of early second-century Gaul and Italy. Similarly, while Roman-British relations are a major theme of Ceva of the Caradocs, Ceva’s continental adventures play little part in forming her opinions, which are decidedly pro-Roman from the start. Finally, The Mark of Edain gives us yet another British prisoner, but in the case of Aoife too her opinions are only confirmed - in this case in their contempt for Rome - by her time at the centre of Empire.

The Grand Tour is a flexible trope. It is of course a vehicle for ideological contestation and display, but also for travel stories, especially those written when foreign travel was the preserve of the few; and a natural backdrop for stories of pursuit, danger and 
hairbreadth 'scapes. In itself it cannot give us a conclusive insight into the relationship between Roman and British identities within fiction of this period, but it offers telling points of comparison, and a useful prism through which to view the variety of ways in which British writers have attempted to make sense of empire, identity, and their own nation's ambiguous relationship with both.

\section{Bibliography}

Butler, Catherine and Hallie O’Donovan. 2012. Reading History in Children’s Books. Basingstoke: Palgrave Macmillan.

Butts, Dennis. 2008. “Exploiting a Formula: the Adventure Stories of G. A. Henty (18321902).” Julia Briggs, Dennis Butts and Matthew Grenby, eds. Popular Children’s Literature in Britain. Aldershiot: Ashgate: 149-63.

Chandler, Pauline. 2008. The Mark of Edain. Oxford: Oxford University Press.

Conrad, Joseph. 1999. Heart of Darkness. Edited by D. C. R. A. Goonetilleke. $2^{\text {nd }}$ Ed. Peterborough, Ont.: Broadview.

Eldridge, Jim. 2008. Roman Invasion (My Story). London: Scholastic, 2008.

Eliott, Lydia. 1953. Ceva of the Caradocs. London: Frederick Warne.

Fletcher, C. R. L. and Rudyard Kipling. A History of England. 1911. Oxford: Clarendon Press.

Gibbon, Edward. 1966. The Decline and Fall of the Roman Empire and Other Selected Writings. [1776] Abridged and edited H. R. Trevor-Roper. Chalfont St Giles: Richard Sadler \& Brown.

Henty, G. A. [n.d.] Beric the Briton: a Story of the Roman Invasion. [1893] London: Blackie and Son, Ltd.] 
Hingley, Richard. 2000. Roman Officers and English Gentlemen: The Imperial Origins of Roman Archaeology. London and New York: Routledge.

Hutton, Ronald. The Druids. London and New York: Hambledon, 2007.

Johnson, Rachel. 2010. "Is Beric a Briton?: the Representation of Cultural Identity in G. A. Henty’s Beric the Briton (1893) and Rosemary Sutcliff's The Outcast (1955). The Journal of Children's Literature Studies 7.2: 75-85.

Trease, Geoffrey. 1956. Word to Caesar. London: Macmillan.

---. Laughter at the Door: A Continued Autobiography. 1974. London: Macmillan.

Treece, Henry. 1954. Legions of the Eagle. London: The Bodley Head. 